УДК 904

https://doi.org/10.24852/2587-6112.2020.5.130.136

\title{
ANIMAL SACRIFICE IN ANCIENT GREECE. BIBLIOGRAPHIC ESSAY
}

\section{(C) 2020, Radwa Salem}

This bibliographic essay addresses the different approaches to animal sacrifice generally with a focus on animal sacrifice in ancient Greece specifically. As animal sacrifice was one of the unfamiliar rituals introduced to western anthropologists by foreign cultures, the ritual of animal sacrifice was addressed by anthropologists as early as the nineteenth century. Later, the topic was a trend in other different majors like archaeology, history, sociology and psychology as well.

Keywords: archaeology, Ancient Greece, anthropology, ritual, sacrifice.

\section{ЖЕРТВОПРИНОШЕНИЕ В ДРЕВНЕЙ ГРЕЦИИ. БИБЛИОГРАФИЧЕСКОЕ ЭССЕ}

\section{Радва Салем}

В данной статье рассматриваются различные подходы к жертвоприношению животных в целом, с акцентом на жертвоприношения животных в Древней Греции. Поскольку принесение в жертву животных было одним из незнакомых ритуалов, представленных западным антропологам иностранными культурами, к ритуалу жертвоприношения животных антропологи обратились еще в XIX веке. Позже эта тема стала трендом и в других специальностях, таких как археология, история, социология и психология.

Ключевые слова: археология, Древняя Греция, антропология, ритуал, жертвоприношение.

The Ancient Greeks saw sacrifice as a way of convincing the gods to answer their prayers, as demonstrated by their proverb "Gifts persuade the gods" (Sacks, 2005, p. 297). The word "gifts" refers to animal sacrifice as well as other kinds of bloodless offerings such as vegetables and libations. However, when comparing the number of studies dealing with animal sacrifice with those studying other bloodless offerings, we can say that scholars considered animal sacrifice as the most important ritual of the Ancient Greek religion.

Both historians and anthropologists treated the topic of animal sacrifice as a part of the wider context of the study of religion and ritual. Early scholarship was dominated by literary approaches, accordingly historians' early approaches to the topic focused on how the Greeks understood the ritual of sacrifice, what kind of offerings were made and where it took place (Harrison, 1903; Stengel, 1910; Nilsson, 1925, 1967). They payed less attention to the social and psychological aspects behind these religions and rituals. However, the topic of animal sacrifice was not a hot one yet, as it was given its importance in modern scholarship after Walter Burkert's "Homo Necans" and René Girard's "Violence and the Sacred" were published in 1972 (Faraone, Naiden, 2012, p. 1). Hence, I would draw a sketch of scholarship by highlighting the works that influenced both Burkert and Girard.

Anthropologists' interest in sacrifice started in Europe as early as the nineteenth century, as a result to the European expansion and contact with foreign cultures (Petropoulou, 2008, p. 1). To begin with, Edward Burnett Taylor was a pioneer anthropologist in the nineteenth century and he was influenced by Darwin's theory of evolution. In his book "primitive culture", Tylor considered religion as something that evolves and moves from primitive to complex. Thus, he suggested that the ritual of sacrifice in its primitive form was beneficiary, a gift to the spirits/souls to gain their support in return. A development of ritual occurred according to Tylor, when the offerings were sacrificed without the motif of gaining a reward. The notion of sacrifice in the last case was a kind of abnegation, it showed morals that indicated a development in civilization (Tylor, 1871, p. 369, 432). Taylor's evolutionist approach was criticized for its ethnocentric and simplistic perspective, as he considered early religions primitive and undeveloped compared to modern day religions (Diah et al, 2014, p. 157-158).

Henri Hubert and Marcel Mauss contributed to the topic by their "Essai sur la nature et la function du sacrifice" in 1899. Hubert and Mauss introduced a new approach in scholarship by using sociology to explain the ritual of sacrifice. 
The aim of their study was "to define the nature and social function of sacrifice" (Hubert, Mauss, 1964, p. 1). They defined sacrifice as a ritual that changes the status of the worshipper from profane to a sacred (Hubert, Mauss, 1964, p. 13). As for the function of sacrifice, they identified it as "a procedure consists in establishing a means of communication between the sacred and the profane world" (Hubert, Mauss, 1964, p. 97). Hence, the role the sacrificed animal played was a mediator between the sacred and the profane.

Hubert and Mauss did not follow on Taylor's evolutionism - yet not totally abandoned it. The way they were influenced by evolutionism is reflected in their opinion that the worshipper did not completely understand the purpose of his actions, for he is still in a "primitive" phase of civilization (Petropoulou, 2008, p. 5). They diverged from the previous theory by moving from explaining the ritual of sacrifice as a gift to explaining it as a mediator between the sacred and the profane (Lincoln, 2012, p. 15).

Karl Meuli introduced a key theory of the study of sacrifice in his article "Griechische Opferbräuche" that was published in 1946. In his article, Meuli coined two different theories that were adopted later by Burkert and Girard. In the first one, he used ethnographic case studies from Siberia where hunters used animal sacrifice as a way of placating the gods. He compared their rituals to the ancient Greek rituals suggesting that animal sacrifice was inherited from early Paleolithic hunters (Meuli, 1946, p. 201-209). The other theory was that the worshipper felt guilt for killing the animals; however, he tried to hide that feeling by claiming a better cause. Meuli called this behavior the comedy of innocence "Unschuldkomödie" (Meuli, 1946, p. 209; Petropoulou, 2008, p. 7).

In the late twentieth century, functionalism replaced evolutionism. Therefore, instead of trying to understand how societies developed, they focused more on how societies functioned (Petropoulou, 2008, p. 6). Influenced by their theories, Walter Burkert introduced a revolutionary approach to the topic of animal sacrifice in his book Homo Necans. He moved from the 'philological-historical positivism' dominating the field in that time, to functionalism (Burkert, 1983, p. xiii). Burkert recycled the theory of Meuli and traced the ritual of animal sacrifice to the Paleolithic, the period in which funerary ritual evolved as well as hunting practices. He drew a conclusion that the killing of wild animals as part of the prehistoric funerary rituals evolved into the sacrifice of animals as a religious ritual (Burkert, 1983, p. 50-51).

Burkert also used sociology and ethology in his approach, by linking between Konrad Lorenz's work "on aggression" and his own previous suggestion of the Paleolithic origins of animal sacrifice. Lorenz suggested that aggression practiced by ritual enhances the sense of community (Lorenz, 2002, p. 71-72). Hence, Burkert concluded that hunting and killing an animal is an aggressive act that banded Prehistoric hunters together creating solidarity among the male society, in a similar manner, killing an animal as a religious ritual in later periods banded people from the same society following the same religion (Burkert, 1983, p. 35).

Girard published his book "la violence et le sacre" in 1972, the same year Burkert published "Homo Necas". In his approach, Girard used the topic of sacrifice as the center of his study of the relationship between human violence and religion (Girard, 1972, p. 9-12). He argued that violence is a part of the human psyche on the one hand, and "the heart and secret soul of the sacred "on the other (Girard, 1987, p. 74).

Since Girard was a professor of French Literature at Stanford University, he used ancient literature and myths in his study. His selection of myths (Milomaki and Oedipus) shows that his interest was not only in sacrifice as the most representative religious act of violence, but also in other kinds of violence such as sexual and emotional violence. He was influenced by Sigmund Freud's theory about the function of sacrifice, in which Freud supposed that sacrifice was the society's way of replacing human-human violence by human-animal violence (Freud, 1919, p. 182-189). Similarly, Girard emphasized the concept of "scapegoat", arguing that sacrifice was the way - violent by origin - humans could cast violence out of their society by using an animal as a scapegoat (Girard, 1987, p. 103-107).

The reception of Homo Necans was quite unresponsive among classists, while Girard's book was well received and was translated into English in 1977. Probably the reason behind this is that Girard's book addressed a wider audience than Burkert's book. However, a decade later, Burkert's work became more popular as the topic was revived in scholarship (Naiden, 2013, p. 9). This revival is reflected in the conference that was held in 1983 at Pajaro Dunes, California. The aim of the conference was a response to a paper written by Burton Mack, in which he analyzed both theories of Burkert and Girard and pointed out 
"areas of agreement and disagreement" (Mack, 1987, p. 51-57). Therefore, the conference was a way of gathering the two scholars for discussion along with Jonathan Z. Smith as a third party, and Renato Rosaldo as an "outsider" commenter on the discussions (Hamerton-Kelly, 1987, p. v).

In the paper he wrote for the conference, Burkert stated that Even though Girard and himself had different approaches to the topic, they both agreed on the same point, that violence is "at the very heart of religion" (Burkert, 1983, p. 2). He explained that agreement by the fact that they both have shared "some common back ground, off course, is provided by Freud's Totem and Taboo and Lorenz's On Aggression" (Burkert, 1987, p. 171).

On the other hand, the paper Jonathan Z. Smith wrote for the same conference criticized one of Burkert's conclusions. While Burkert assumed that sacrifice's origin goes back to the killing rituals of the Paleolithic hunters, Smith completely refused Burkert's search for origins of sacrifice. Having said that, Smith himself argued that sacrifice was "originally" a domesticated ritual that could not have happened in pre-agrarian periods. According to Smith, sacrifice is giving away from one's property; therefore, it appeared as a ritual after the domestication of animals, the period in which the concept of property developed (Smith, 1987, p. 196-198). Even though Smith had his own theory about the origin of sacrifice he explained his rejection to the idea of research for origins by the fact that scholars select the data that support their theory thus "there is no primordium; it's all application. Everything is elaboration; so I refuse the questions of origin" (Smith, 1987, p. 207).

Furthermore, Smith excluded one of Burkert's research methodologies that is phenomenology. Therefore, his interest was in the facts of the ritual of sacrifice rather than humans' emotions and the psychological significance of ritual. Smith's rationalist approach cannot be exclusively applied on the study of religion, as religion cannot be studied without considering the human psychology and motivation (Petropoulou, 2008, p. 10; Mack, 1987, p. 50). I think the rationalist approach to religion fails to understand the function of rituals, as rituals are not necessarily rational.

By the end of the twentieth century, the interest of scholars shifted from focusing on the violence aspect of sacrifice to the phase following the act of killing, which is the feast after the sacrifice itself (Faraone, Naiden, 2012, p. 1). The French school of Marcel Detienne and Jean-Pierre Vernant who published their work "The Cuisine of Sacrifice among the Greeks" in 1989 adopted this approach. They used literary sources to describe the process of sacrifice itself, how the different species of animals were killed, how the meat was distributed and cooked, and who attended the feast after the sacrifice (Vernant, 1977, p. 57; Vernant, 1989, p. 42-43; Detienne, 1989, p. 11-13).

The school of Vernant and Deteinne moved from the anthropological theories of the German functionalism to the French structuralism. To that end, they studied sacrifice in its own context as a part of the larger structure of both religion and society instead of studying it in isolation. They argued that the Greeks did not understand sacrifice as a violent ritual, as the notion of violence was covered by the meal after the murder of the animal (Deteinne, 1989, p. 7.).

I think their work provides a good example of Smith's opinion about the scholars' selective manner in research. To prove their theory, they focused on Buphonia, a type of sacrifice followed by a festival, in order to shed the light on the joy and pleasure of the ritual of sacrifice rather than the violence of killing.

Burkert's approach focused on the act of killing while the school of Vernant focused on the consumption of meat. Both approaches overlooked other aspects of Ancient Greek ritual by overestimating animal sacrifice over other types of bloodless offerings, and aggression over the aesthetic aspect of ritual (Naiden, 2015, p. 466-467).

The topic then moved to iconography as another tool for research by Sarah Peirce. In her article "Death, Revelry and Thysia", Sarah argued that the Greeks saw sacrifice as a joyful occasion. Thus, they depicted the function of the ritual, which is joy, rather than the murder of the animals. Hence, animals were depicted without fearsome expressions (Pierce, 1993, p. 257-258). Van Straten also used iconography and shed the light on three specific moments of ritual. The pre-kill moment when the animal was brought to alter, the killing moment, and the post-kill moment when it was cooked (Van Straten, 1995, p. 13, 104, 115). He did not offer a conclusion to explain the rare depiction of the moment of kill, but I think the outcome of his study supports Pierce's conclusion.

Even after three decades and despite all criticism, the theories of Burkert and Vernant still influence recent scholarship, and the new 
approaches are built upon the old ones. As Graf noted, we all stand on the shoulders of giants (Graf, 2002, p. 124).

Ten years later, in the book edited by Cristopher Faraone and Fred Naiden, Greek and Roman Animal Sacrifice: Ancient Victims, Modern Observers, Graf criticized these grand theories because they were built upon negative anthropology (Graf, 2012, p. 40) thus, cannot be recycled. Significantly, two articles in the same volume had literary approaches to sacrifice; both influenced by Vernant's Hesiodic framework (Redfield, 2012; Henrichs, 2012).

Current scholarship broke out from these theories by questioning the importance of animal sacrifice itself in the Greek religion. Moreover, to what extent can our information about the number of population help us estimate the amount of meat produced by sacrifice (Erkoth, 2002; 2007; Petropoulou, 2008; Naiden, 2012, 2013).

Naiden argued that the ancient Greek language did not have a specific term to express sacrifice. The common word was thuein, which means, "to smoke". In addition to the term hiera rezein which means "to do sacred things". Hence, other rituals complemented the ritual of sacrifice like prayers and oracles, and are as important as the sacrifice itself (Naiden, 2015, p. 463).

To sum up, trends in scholarship seem to follow the fashion of its age and scholars' personal backgrounds. With this in mind, Taylor interpreted sacrifice as a primitive ritual; this could be due to the ethnocentric perspective dominating western anthropologists during the nineteenth century.

Moreover, Meuli diverged from Taylor's approach by applying ethology. His theory of Unschuldkomödie shed the light on the notion of guilt. Explicably, he was influenced by the political events of his time. He was a SwissGerman scholar who published his article right after the World War II when the crimes of the Nazis were widely known. Hence, he emphasized that even though the Nazis claimed innocence of their violent acts, they knew that they were guilty (Lincoln, 2012, p. 28). In a similar manner, the Greeks claimed a higher purpose of sacrifice, yet they felt guilty about killing the animal.

In the twentieth century, sacrifice moved away from evolutionism to functionalism and structuralism. Significantly, the great theories of that century which represented the framework for later theories had two different perceptions. For Burkert on the one hand emphasized on the domination of violence in religious rituals, while Vernant excluded emotions from his approach. Graf offered a biographical explanation to these two different approaches to the topic. He noted that Vernant was a commander in Second World War, so he was familiar with death. Burkert on the other hand stated in an interview that he could not forget his emotional shock when his father killed their rabbit for food (Graf, 2012, p. 42).

At the same time, Burkert and the school of Vernant shared two things. First: they privileged animal sacrifice to all other offerings, second: they emphasized the role of animal sacrifice in male bonding and social cohesion (Faraone, Naiden, 2012, p. 2.). They did not pay much attention to other bloodless offerings nor other aspects of ritual like prayers and the significance of place where all this happened.

Graf referred Burkert, Girard and Vernant's focus on animal sacrifice to their religious background as "all three promoted sacrifice to the most important ritual act of pre-Christian religions, eerily echoing much more the church fathers in their assessment of pagan religions than those pagans themselves" (Graf, 2012, p. 32).

The application of iconography did not add much to the topic, it rather recycled Vernant's theory by shedding the light on the joyful aspect of sacrifice rather than violence or the notion of guilt. The most recent approaches on the other hand, are more concerned with the rituals that accompanied sacrifice. I think the scholarship starting from Burkert's work until now is complementary rather than contradictory. For the study of religion requires combing different approaches in order to understand why, how and where worshippers performed certain rituals, hence, deliver a more complete picture of the Greek religion.

\section{BIBLIOGRAPHY}

Burkert W. Homo Necans: The Anthropology of Ancient Greek Sacrificial Ritual and Myth. Translated by P. Bing. California, 1983. 360 p.

Burkert W. The Problem of Ritual Killing. // Violent Origins: Walter Burkert, Rene Girard and Jonathan Z. Smith on Ritual Killing and Cultural Formation / Hamerton-Kelly, R. G. (ed.) California, 1987. P. 149-190.

Detienne M. Culinary Practices and the Spirit of Sacrifice. In: Detienne, M. and J. Vernant (eds.) The Cuisine of Sacrifice among the Greeks. Chicago, 1989. P. 1-20. 
Diah N.M., Hossain M.D., Mustari S., Ramli N.S. An Overview of the Anthropological Theories // International Journal of Humanities and Social Science, 2014. №4. P. 155-164.

Erkoth $G$. The Sacrificial Rituals of Greek Hero-Cults in the Archaic to the Early Hellenistic Period. Liège, 2002. $429 \mathrm{p}$.

Faraon C. A., Naiden F.S. Introduction // Greek and Roman Animal Sacrifice: Ancient Victims, Modern Observers / Faraone, C. A. and F. S. Naiden (eds.), Cambridge, 2012. P. 1-12.

Freud $S$. Totem and taboo: resemblances between the psychic lives of savages and neurotics. Translated by A. A. Brill. London, 1919. 268 p.

Girard R. Generative Scapegoating // Violent Origins: Walter Burkert, Rene Girard and Jonathan Z. Smith on Ritual Killing and Cultural Formation / Ed. Hamerton-Kelly, R. G. California, 1987. P. 73-148.

Graf F. One Generation after Burkert and Girard: Where are the Great Theories? // Greek and Roman Animal Sacrifice: Ancient Victims, Modern Observers / Eds. Faraone, C.A. and F. S. Naiden. Cambridge, 2012. P. 32-54.

Graf F. What is New about Greek Sacrifice? // Kykeon: Studies in Honour of H. S. Versnel. / Horstmanshoff, H. F. J., H. W. Signor, F. T. Van Straten and J. H. M. Strubbe (eds.). Leiden, 2002. P. 113-125.

Hamerton-Kelly R. G. Preface // Violent Origins: Walter Burkert, Rene Girard and Jonathan Z. Smith on Ritual Killing and Cultural Formation / Hamerton-Kelly, R. G. (ed.) California, 1987. P. V-IX.

Harrison J. E. Prolegomena to the study of Greek Religion. Cambridge, 1903. 716 p.

Henrichs A. Animal Sacrifice in Greek Tragedy: Ritual, Metaphor, Problematizations. // Greek and Roman Animal Sacrifice: Ancient Victims, Modern Observers / Eds. Faraone, C.A. and F. S. Naiden. Cambridge, 2012 P. 180-194.

Hubert H., Mauss M. Essays on the Nature and Function of Sacrifice. Translated by W. Hall. Chicago, 1964. $176 \mathrm{p}$.

Lincoln B. From Bergaigne to Meuli: how animal sacrifice became a hot topic. // Greek and Roman Animal Sacrifice: Ancient Victims, Modern Observers / Faraone, C. A. and F. S. Naiden (eds.). Cambridge, 2012. P. 13-31.

Lorenz K. On Aggression. Translated by: M. K. Wilson. London, 2002. 306 p.

Mack B. Introduction: Religion and Ritual // Violent Origins: Walter Burkert, Rene Girard and Jonathan Z. Smith on Ritual Killing and Cultural Formation / Hamerton-Kelly, R. G. (ed.) California, 1987. P. 1-72.

Meuli K. 'Griechische Opferbräuche', // Phyllobolia für Peter von der Mühll zum 60. Geburtstag am 1. August 1945 (Basel: B. Schwabe). / Gigon, O. (ed.). 1946. P. 185-288.

Naiden F.S. Blessed are the Parasites // Greek and Roman Animal Sacrifice: Ancient Victims, Modern Observers / Faraone, C. A. and F. S. Naiden (eds.), Cambridge, 2012. P. 55-83.

Naiden F. Sacrifice // The Oxford Handbook of Ancient Greek Religion / Eidinow E. and J. Kindt (eds.). Oxford, 2015. P. 463-476.

Naiden F. Smoke Signals for the Gods. Ancient Greek sacrifice from the Archaic through Roman periods. Oxford, 2013. 421 p. DOI:10.1093/acprof:oso/9780199916405.001.0001

Nilsson M. P. A History of Greek Religion. Translated by: F. J. Fielden. Oxford, 1925. Doi: 10.2307/625094

Nilsson M. P. Geschichte der griechischen Religion. Third edition. Munich, 1967. P. 486-487.

Peirce S. Death, Revelry, and "Thysia". Classical Antiquity 12, no. 2. 1993. P. 219-66.

Petropoulou M. Animal Sacrifice in Ancient Greek Religion, Judaism, and Christianity: 100 BC- AD 200. Oxford, 2008.

Redfield J. Animal Sacrifice in Comedy: An Alternative Point of View. // Greek and Roman Animal Sacrifice: Ancient Victims, Modern Observers. / Faraone, C. A. and F. S. Naiden (eds.), Cambridge, 2012. P. 167-179.

Sacks D. Sacrifice. The Encyclopedia of the Ancient Greek World. Revised Edition. Revised by Lisa R. Brody. Consultant editor Oswyn Murray. New York, 2005. 412 p.

Smith J. Z. The Domestication of sacrifice. In: Hamerton-Kelly, R. G. (ed.) Violent Origins: Walter Burkert, Rene Girard and Jonathan Z. Smith on Ritual Killing and Cultural Formation. California, 1987. P. 191-238.

Stengel P. Opferbräuche der Griechen. Leipzig, 1910. 238 p.

Tylor E.B. Primitive Culture: Researches into the Development of Mythology, Philosophy, Religion, Art, and Custom. London, 1871. 455 p. 
Van Straten F. T. Hiera Kala: Images of Animal Sacrifice in Archaic and Classical Greece. Leiden, 1995. $374 \mathrm{p}$.

Vernant J. At Man's Table Hesiod's Foundation Myth of Sacrifice // The Cuisine of Sacrifice among the Greeks / Eds. Detienne, M. and J. Vernant Chicago, 1989. P. 21-87.

Vernant J. Sacrificial and Alimentary Codes in Hesiod's Myth of Prometheus. // Myth, Religion and Society / Ed. R. L. Gordon. Cambridge, 1981. P. 57-79.

\section{About the Author:}

Radwa Salem, PhD student, Selçuk University (Konya, Turkey); Rms796@student.bham.ac.uk

\section{REFERENCES}

Burkert, W. 1983. Homo Necans: The Anthropology of Ancient Greek Sacrificial Ritual and Myth. Translated by P. Bing. California.

Burkert, W. 1987. In Hamerton-Kelly, R. G. (ed.) Violent Origins: Walter Burkert, Rene Girard and Jonathan Z. Smith on Ritual Killing and Cultural Formation. California, 1987, 149-190.

Detienne, M. 1989. In Detienne, M. and J. Vernant (eds.) The Cuisine of Sacrifice among the Greeks. Chicago, 1-20.

Diah, N. M., Hossain, M. D., Mustari, S., Ramli, N. S. 2014. In International Journal of Humanities and Social Science, 4, 155-164.

Erkoth, G. 2002. The Sacrificial Rituals of Greek Hero-Cults in the Archaic to the Early Hellenistic Period. Liège.

Faraon C. A., Naiden F.S. 2012. Introduction. In Faraone, C. A. and F. S. Naiden (eds.), Greek and Roman Animal Sacrifice: Ancient Victims, Modern Observers. Cambridge, 1-12.

Freud, S. 1919. Totem and taboo: resemblances between the psychic lives of savages and neurotics. Translated by A. A. Brill. London.

Girard, R. 1987. In Hamerton-Kelly, R. G. (ed.) Violent Origins: Walter Burkert, Rene Girard and Jonathan Z. Smith on Ritual Killing and Cultural Formation. California, 73-148.

Graf, F. 2012. In Faraone, C.A. and F. S. Naiden (eds.). Greek and Roman Animal Sacrifice: Ancient Victims, Modern Observers Cambridge, 32-54.

Graf, F. 2002. In Horstmanshoff, H. F. J., H. W. Signor, F. T. Van Straten and J. H. M. Strubbe (eds.). Kykeon: Studies in Honour of H. S. Versnel. Leiden, 113-125.

Hamerton-Kelly, R. G. 1987. In: Hamerton-Kelly, R. G. (ed.) Violent Origins: Walter Burkert, Rene Girard and Jonathan Z. Smith on Ritual Killing and Cultural Formation. California, V-IX.

Harrison, J. E. 1903. Prolegomena to the study of Greek Religion. Cambridge.

Henrichs, A. 2012. In Faraone, C.A. and F. S. Naiden (eds.). Greek and Roman Animal Sacrifice: Ancient Victims, Modern Observers Cambridge, 180-194.

Hubert, H., Mauss, M. 1964. Essays on the Nature and Function of Sacrifice. Translated by W. Hall. Chicago.

Lincoln, B. 2012. Faraone, C. A. and F. S. Naiden (eds.). Greek and Roman Animal Sacrifice: Ancient Victims, Modern Observers. Cambridge, 13-31.

Lorenz, K. 2002. On Aggression. In Wilson M. K. (trans1.). London.

Mack B. 1987. In Hamerton-Kelly, R. G. (ed.) Violent Origins: Walter Burkert, Rene Girard and Jonathan Z. Smith on Ritual Killing and Cultural Formation. California, 1-72.

Meuli, K. 1946. In Gigon, O. (ed.). Phyllobolia für Peter von der Mühll zum 60. Geburtstag am 1. August 1945 (Basel: B. Schwabe), 185-288 (in German)

Naiden, F. S. 2012. In Faraone, C. A. and F. S. Naiden (eds.). Greek and Roman Animal Sacrifice: Ancient Victims, Modern Observers. Cambridge, 55-83.

Naiden, F. 2015. In Eidinow E. and J. Kindt (eds.). The Oxford Handbook of Ancient Greek Religion. Oxford, 463-476.

Naiden, F. 2013. Smoke Signals for the Gods. Ancient Greek sacrifice from the Archaic through Roman periods. Oxford. DOI:10.1093/acprof:oso/9780199916405.001.0001

Nilsson, M. P. 1925. A History of Greek Religion. In F. J. Fielden (trasl.). Oxford. Doi: 10.2307/625094 
Nilsson, M. P. 1967. Geschichte der griechischen Religion. Third edition. Munich (in German).

Peirce, S. 1993. In Classical Antiquity 12 (2), 219-66.

Petropoulou, M. 2008. Animal Sacrifice in Ancient Greek Religion, Judaism, and Christianity: 100 BC$A D$ 200. Oxford.

Redfield, J. 2012. In Faraone, C. A. and F. S. Naiden (eds.) Greek and Roman Animal Sacrifice: Ancient Victims, Modern Observers. Cambridge.

Sacks, D. 2005. Sacrifice. The Encyclopedia of the Ancient Greek World. Revised Edition. Revised by Lisa R. Brody. Consultant editor Oswyn Murray. New York.

Smith J. Z. 1987. The Domestication of sacrifice. In Hamerton-Kelly, R. G. (ed.) Violent Origins: Walter Burkert, Rene Girard and Jonathan Z. Smith on Ritual Killing and Cultural Formation. California, P. 191-238.

Stengel, P. 1910. Opferbräuche der Griechen. Leipzig. (in German).

Tylor, E. B. 1871. Primitive Culture: Researches into the Development of Mythology, Philosophy, Religion, Art, and Custom. London.

Van Straten, F. T. 1995. Hiera Kala: Images of Animal Sacrifice in Archaic and Classical Greece. Leiden.

Vernant J. 1989. At Man's Table Hesiod's Foundation Myth of Sacrifice. In Detienne, M. and J. Vernant (eds.). The Cuisine of Sacrifice among the Greeks. Chicago, P. 21-87.

Vernant, J. 1981. Sacrificial and Alimentary Codes in Hesiod's Myth of Prometheus. In. Gordon, R. L. (ed.). Myth, Religion and Society. Cambridge, 57-79.

\section{Информация об авторе:}

Радва Салем, аспирант, Университет Сельчук (г. Конья, Турция); Rms796@student.bham.ac.uk

Статья поступила в журнал 01.08.2020 г. Статья принята к публикации 01.09.2020 г. 